\title{
Enhanced Liver Fibrosis Score
}

National Cancer Institute

\section{Source}

National Cancer Institute. Enhanced Liver Fibrosis Score. NCI Thesaurus. Code C132429.

A scoring system for liver fibrosis developed by Lichting hagen et al, based on an algorithm that takes into account tissue inhibitor of metalloproteinases 1 (TIMP-1), amino-terminal propeptide of type III procollagen (PIIINP) and hyaluronic acid (HA) levels. (Lichting hagen R, Pietsch D, Bantel H, Manns MP, Brand K, Bahr MJ. The Enhanced Liver Fibrosis (ELF) score: normal values, influence factors and proposed cut-off values. J

Hepatol. 2013 Aug;59(2):236-42.) 